\title{
New Zinc (II) Phthalocyanines Substituents: Synthesis, Aggregation Behavior, Antioxidant, and Antibacterial Activity
}

\author{
Abdennasser JLALI ${ }^{1 *}$, Bassem JAMOUSSI ${ }^{2}$ \\ ${ }^{1}$ Laboratory of Supramolecular Chemistry ISEFC, Faculty of Sciences Bizerte, University of Carthage.Tunisia \\ ${ }^{2}$ Laboratory of Supramolecular Chemistry ISEFC, University Virtual-Tunisia
}

\begin{abstract}
The novel phthalonitrile derivatives bearing methyl 2-mercaptoacetate and methyl 3-mercaptopropanoate phthalonitrile substituents at peripheral position were preparedby a nucleophilic displacement reaction. Cyclotetramerization of these phthalonitrile derivatives in the presence of corresponding metal salts gave the new metallophthalocyanines. The novel compounds were characterized by using various spectroscopic data. The aggregation investigations carried out in different concentrations indicate that phthalocyanine compounds do not have any aggregation behavior for the concentration range of $10^{-4}-10^{-6} \mathrm{M}$ in tetrahydrofuran. In vitro three antioxidant test methods, namely (2, 2-diphenyl-1-picryl-hydrazyl) radical scavenging activity was used to determine the antioxidant activity of compounds. In addition to these, the antibacterial activities of compounds were investigated by using the disk-diffusion method.
\end{abstract}

Keywords: Phthalocyanines, Synthesis, aggregation, antioxidant,antibacterial activity

\section{Introduction}

Phthalocyanines (Pcs) are one of the important tetrapyrrole derivatives, formally known as tetrabenzo [5,10,15,20]tetraazaporphyrins, are more stable analogs of the porphyrins and porphyrazines, but ,unlike porphyrins, they do not occur in nature as they are totally synthetic compounds [1]. The fully conjugated $18 \pi$ electronic structure of Pcs gives to their structure, good thermal, optical stability and intense absorption bands in visible area. Thanks to these special and exclusive properties, Pcs have led to numerous interests in many fields, such as therapeutic medicine, photosensitizers for photodynamic therapy of cancer (PDT)[2] and antioxidant[3]. Besides, many otherapplications have appeared, including nonlinear optics [4], optical filters [5], liquidcrystalline electronic charge carriers [6], Langmuir-Blodgett films [7], chemical sensor [8], ink-jet printing [9], optical read-write disks [10], catalysis [11], layers of gas sensors [12] solar cells [13], exciton-transport materials, semi- conductors[14] in addition to their traditional use as dyes and pigments [15]. Due to the intermolecular interactions between the macrocycles, many metal free phthalocyanines(Pcs) and metallophthalocyanines compounds are generally insoluble in organic solvents. To solve this problem, introducing different types of substituents such as alkyl, alkoxyl, alkylthio and macrocyclic groups into the peripheral of the phthalocyanine ring or changing the metal ion are used[16].

In this study, we focused on the synthesis of phthalocyanines bearing methyl 2-mercapto-acetate and methyl 3mercaptopropanoate phthalonitrile substituents on the peripheral positions. We have also reported the results of a comprehensive investigation of the concentration effects on the aggregation properties of phthalocyanine derivatives in THF. Moreover, these new compounds were investigated for antioxidant and antibacterial activities.

\section{Experimental}

\subsection{Materials and Equipment}

N,N-dimethylformamide (DMF), dimethyl-sulfoxide (DMSO), dichloromethane (DCM), 1-pentanol, n-hexane, chloroform $(\mathrm{CHCl} 3)$ and ethanol $(\mathrm{C} 2 \mathrm{H} 5 \mathrm{OH})$ were freshly used (potassium carbonate $\left(\mathrm{K}_{2} \mathrm{CO}_{3}\right)$, zinc acetate $\left(\mathrm{Zn}(\mathrm{OAc})_{2}\right)$, 1,8-diazabicyclo[5.4.0] undec-7-ene (DBU) and thiols were used as received from Aldrich. 4- nitrophtalonitrile was synthesized in our laboratory starting with the phthalimide according to the literature procedure [17].

1H-NMR and 13C-NMR spectral data were obtained by Varian 300 FT-NMR. Spectrometer FTIR spectra were acquired on a Perkin-Elmer BX FT-IR system spectrometer by dispersing sample in $\mathrm{KBr}$ pellets. UV-Visible absorption spectra were recorded on a Cary 2300 spectro-photometer. Mass spectra were obtained using an Autoflex III ( Bruker) with electron impact (EI) ionization methods. Elemental analysis was done using a Vario-ElementarMicrocube EL III. Mass spectral data were collected with a BrukerAutoflex III Smartbeam TOF/TOF Mass spectrometer.

\subsection{Synthesis}

\subsection{1 (Methyl 2-mercaptoacetate) phthalonitrile (2)}

Methyl 2-mercaptoacetate $(1.5 \mathrm{~g}, 14.45 \mathrm{mmol})$ and 4nitrophthalonitrile 1 ( $2.5 \mathrm{~g}, 14.45 \mathrm{mmol})$ were dissolved in $10 \mathrm{~mL}$ DMF. The mixture was stirred at room temperature under nitrogen atmosphere. After stirring for $15 \mathrm{~min}$, dry potassium carbonate $\mathrm{K}_{2} \mathrm{CO}_{3}(2 \mathrm{~g}, 14.5 \mathrm{mmol})$ was added in small portions during $2 \mathrm{~h}$ with efficient stirring and the reaction mixture left to stir for a further $72 \mathrm{~h}$ at room temperature. The mixture was then added water $(150 \mathrm{~mL})$ and stirred for $15 \mathrm{~min}$. The resulting precipitatewas filtered off, thoroughly washed with diethyl ether andacetone, dried and recrystallized from an ethanol: Yield: (90\%). Mp: 129 ${ }^{\circ} \mathrm{CMp}: 130{ }^{\circ} \mathrm{C} .{ }^{1} \mathrm{H} \mathrm{NMR}\left(300 \mathrm{MHz}, \mathrm{CDCl}_{3}\right)$ : $\delta$, ppm: 7.9 (s, 


\section{International Journal of Science and Research (IJSR) \\ ISSN (Online): 2319-7064}

Index Copernicus Value (2013): 6.14 | Impact Factor (2015): 6.391

1H-Ar); 7,6-7.7 (2d, 1H-Ar); 7,4 (d,1H-Ar); 4,1 (s, 2H, $\left.\mathrm{CH}_{2}\right) ; 3,5\left(\mathrm{~s}, 3 \mathrm{H},-\mathrm{CH}_{3}\right) .{ }^{13} \mathrm{C} \mathrm{NMR}\left(75 \mathrm{MHz}, \mathrm{CDCl}_{3}\right)$ : $\delta$, ppm: $172.4,145.6,136.1,130.7,120.8,117.3,115,54.2,35.1$ FTIR $v_{\max } / \mathrm{cm}^{-1}: 3005(\mathrm{C}-\mathrm{H}), 2226(\mathrm{C} \equiv \mathrm{N}), \quad 1735,1750$ $(\mathrm{C}=\mathrm{O}), 1641,1603(\mathrm{C}=\mathrm{C}), 1437,1408,1387(\mathrm{C}-\mathrm{H}), 910-827$ (C-S-C). Anal calculated for $\mathrm{C}_{11} \mathrm{H}_{8} \mathrm{O}_{2} \mathrm{~N}_{2} \mathrm{~S}$ : C, 56.83; H, 3.44; N, 12.05; S, 13.80\%; Found: C, 56.87; H, 3.40; N, 12.44; S, $13.51 \%$. Mass $\mathrm{m} / \mathrm{z}(\mathrm{EI}, 30 \mathrm{eV}): \mathrm{M}^{+} 232.26$.

\subsection{2(Methyl 3-mercaptopropanoate) phthalonitrile(3)}

The synthesis for $\mathbf{3}$ was the same as for $\mathbf{2}$ except methyl 3mercaptopropanoate $(1.7 \mathrm{~g}, 14.45 \mathrm{mmol})$ was employed instead of methyl 2-mercaptoacetate. The amounts of the reagents were the same as for 2 . Yield: $(87 \%)$. Mp: $132{ }^{\circ} \mathrm{C}$. ${ }^{1} \mathrm{H}$ NMR(300 MHz, $\mathrm{CDCl}_{3}$ ): $\delta$, ppm: 7.9 (s, 1H-Ar); 7,6-7.7 (2d, 1H-Ar); 7,4 (d,1H-Ar); 3,8 (s, 3H, - $\left.\mathrm{CH}_{3}\right) ; 3.2-3.15(\mathrm{~m}$, $\left.2 \mathrm{H},-\mathrm{CH}_{2}\right), 2.6-2.57\left(\mathrm{~m}, 2 \mathrm{H},-\mathrm{CH}_{2}\right) .{ }^{13} \mathrm{C} \mathrm{NMR}(75 \mathrm{MHz}$, $\left.\mathrm{CDCl}_{3}\right)$ : $\delta$,ppm: $175.2,150.4,136.1,133.2,125.4,120.3$, 115.7, 54.9, 34.1, 31.3.FTIR $v_{\max } / \mathrm{cm}^{-1}: 3020(\mathrm{C}-\mathrm{H}), 2232$, $(\mathrm{C} \equiv \mathrm{N}), 1735,1750(\mathrm{C}=\mathrm{O}), 1671,1605(\mathrm{C}=\mathrm{C}), 1441,1418$, 1390 (C-H), 914-839 (C-S-C). Anal calculated for $\mathrm{C}_{12} \mathrm{H}_{10} \mathrm{O}_{2} \mathrm{~N}_{2} \mathrm{~S}$ : C, 58.46; H, 4.06; N, 11.36; S, 12.99\%; Found: C, 58.40; H, 4.12; N, 11.31; S, $13.04 \%$. Mass m/z (EI, $30 \mathrm{eV}): \mathrm{M}^{+} 246.29$.

2.2.3 2,10,16,24-Tetrakis (methyl 2-mercaptoacetate) phthalocyanine zinc (II) (4)

A mixture of compound $2(0.1 \mathrm{~g}, 0.448 \mathrm{mmol})$, anhydrous zinc acetateZn $(\mathrm{OAc})_{2}(0.097 \mathrm{~g}, 0.448 \mathrm{mmol})$ and1,8diazabicyclo[ 5.4.0] undec-7-ene (DBU) $(0.1 \mathrm{~mL}, 0.67$ mmol) indry 1-pentanol $(2 \mathrm{~mL})$ was stirred and heated at reflux temperature under an argon atmospherefor $12 \mathrm{~h}$. After cooling to room temperature, the reaction mixture was precipitated by adding it drop wise into n-hexane. The crude product was precipitated, collected by filtration and washed with hot hexane, ethanol and methanol. The crude green product was further purified by chromatography over a silica gel column using $\mathrm{CH}_{2} \mathrm{Cl}_{2}$ and a mixture of $\mathrm{CH}_{2} \mathrm{Cl}_{2}$-ethanol (10:1 by volume), as eluents. Yield $39 \% .{ }^{1} \mathrm{H}$ NMR $(300 \mathrm{MHz}$, $\left.\mathrm{CDCl}_{3}\right): \delta$, ppm: 7.54-7.06 (m, 8H, Ar-H); 6.88 (s, 4H, Ar$\mathrm{H}) ; 4.25\left(\mathrm{~m}, 8 \mathrm{H},-\mathrm{CH}_{2}\right) ; 3.7\left(\mathrm{~s}, 12 \mathrm{H},-\mathrm{CH}_{3}\right)$. FTIR $v_{\max } / \mathrm{cm}^{-1}$ : $3098(\mathrm{C}-\mathrm{H}), 1745-1725(\mathrm{C}=\mathrm{O}), 1437-1407(\mathrm{C}=\mathrm{C}), 1290$ 1095 (C-O), 716 (C-S-C).UV-Vis (THF) $\lambda_{\max }, \mathrm{nm}(\log \varepsilon)$ : 340(4,42) 616(4,18), 678(4,49).MALDI-TOF-MS m/z: Calc.: 985.50. Found: $987.09[\mathrm{M}+2]^{+}$for $\mathrm{C}_{44} \mathrm{H}_{32} \mathrm{~N}_{8} \mathrm{~S}_{4} \mathrm{O}_{8} \mathrm{Zn}$.

\subsubsection{2, 10, 16, 24-Tetrakis4 (methyl 2-hydrosulfonyl-} acetate) phthalocyanine zinc (II) (5)

The procedure is the same with the synthesis of compound $\mathbf{5}$, except it is the compound $\mathbf{3}$ that will be used instead of compound 2.Yield $37 \%$. ${ }^{1} \mathrm{H}$ NMR $\left(300 \mathrm{MHz}, \mathrm{CDCl}_{3}\right): \delta$, ppm: 8.01(m, $8 \mathrm{H}, \mathrm{Ar}-\mathrm{H}) ; 6.87(\mathrm{~s}, 4 \mathrm{H}, \mathrm{Ar}-\mathrm{H}) ; 4.1\left(\mathrm{~s}, 12 \mathrm{H},-\mathrm{CH}_{3}\right)$; $2.65\left(\mathrm{~m}, 16 \mathrm{H},-\mathrm{CH}_{2}\right) \quad$ FTIR $v_{\max } / \mathrm{cm}^{-1}: 3090(\mathrm{C}-\mathrm{H}), 1750-$ $1705(\mathrm{C}=\mathrm{O}), 1420-1405(\mathrm{C}=\mathrm{C}), 1273-1080(\mathrm{C}-\mathrm{O}), 698$ (C-SC).UV- Vis (THF) $\lambda_{\max }, \mathrm{nm}(\log \varepsilon): 340(4,42) 616(4,18)$,
678(4,49).MALDI-TOF-MS m/z: Calc.: 1041.48. Found: $1042.61[\mathrm{M}+1]^{+}$for $\mathrm{C}_{48} \mathrm{H}_{40} \mathrm{~N}_{8} \mathrm{~S}_{4} \mathrm{O}_{8} \mathrm{Zn}$.

\subsection{Antibacterial effect of compounds}

In vitro antibacterial activity of DMSO solution of compounds was experimented against gram-positive bacteria (Micrococcus luteus (ATCC 9341), Bacillus subtilis (6051), Staphylococcus aureus (ATCC 6538) and Enterococcus hirae (ATCC10541), gram-negative bacteria (Escherichia coli (ATCC 10536) and Pseudomonas aeruginosa (ATCC 9027)) were appraised via the disk-diffusion method. $15 \mathrm{~mL}$ solution of compounds in DMSO at a concentration of 500 $\mu \mathrm{g} / \mathrm{mL}$, was used to soak the Sterile blank antibacterial test discs (6 mm diameter, Oxoid) which were later dried and placed on nutrient agar plates. The plates were incubated at $37^{\circ} \mathrm{C}$ for $24 \mathrm{~h}$, then the inhibition zones were measured in $\mathrm{mm}$. Fifteen microliters of DMSO played the role of a negative control, while Amikacin (30 $\mu \mathrm{g} /$ disk) and Tetracycline (30 $\mu \mathrm{g} / \mathrm{disk})$ were used as positive controls[18].

\subsection{DPPH radical scavenging activity}

DPPH (2,2-diphenyl-1-picryl-hydrazyl) radical scav-enging activity of all compounds was studied by applying the method described in literature with some modifications [19]. Briefly, $0.5 \mathrm{~mL}$ of DMF solution of the test compounds was added to $2 \mathrm{~mL}$ of methanolic solution of DPPH. The final concen-trations of the test compounds in the reaction mixtures were $5,10,25,50$ and $100 \mathrm{mg} / \mathrm{L}$. The mixture was shaken vigorously andhad been incubated for $30 \mathrm{~min}$ at room temperature in the dark. The decrease in absorbance of DPPH at $517 \mathrm{~nm}$ was measured afterwards. A control reaction was experimented without the DMF solution of compounds. DMF solution was used as the blank control. The DPPH scavenging activity was calculated according to the equation:

Scavenging activity $(\%$ control $)=\left(\mathrm{A}_{\text {control }}-\mathrm{A}_{\text {sample }}\right) / \mathbf{A}_{\text {control }} \times 100$

Where $\mathrm{A}_{\text {sample }}$ is the absorbance in the presence of sample and $\mathrm{A}_{\text {control }}$ is the absorbance in the absence of sample, respectively. Experimental results were compared with Ascorbic acid and Trolox. The obtained data are the arithmetic mean of three measurements

\section{Results and discussion}

\subsection{Synthesis and characterization}

The synthetic route followed for the synthesis of phthalonitrile derivatives $\mathbf{2}$ and $\mathbf{3}$ and novel thiol-derivatized zinc(II) phthalocyaninescomplexes $\mathbf{4}$ and $\mathbf{5}$ are given inScheme1. 


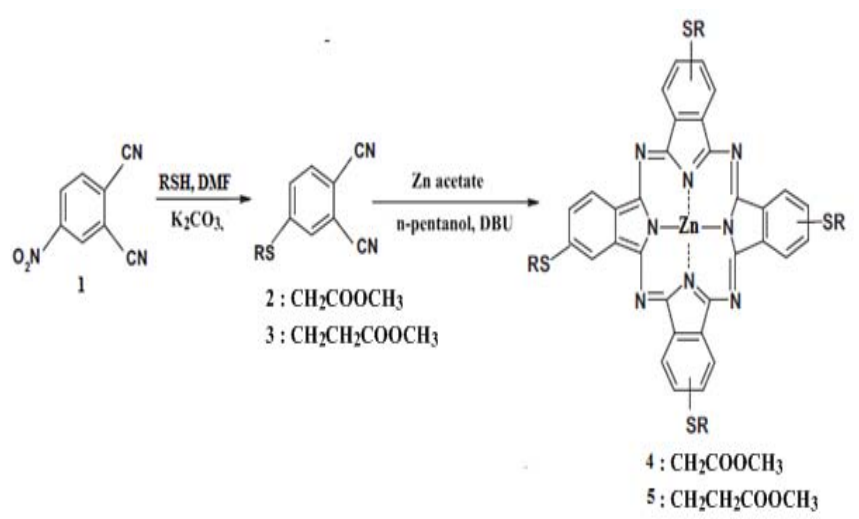

Scheme 1: The synthetic route of the novel compounds (25).

Phthalonitrile derivatives $\mathbf{2}$ and $\mathbf{3}$ were obtained through the reaction of nucleophilic substitution reaction between 4nitrophthalonitrile and methyl 2-mercaptoacetate or methyl 3-mercaptopropanoate at room temperature under nitrogen atmosphere in dry DMF in the presence of $\mathrm{K}_{2} \mathrm{CO}_{3}$ as a basewith $87 \%$ yield (Scheme 1). This reaction has been used in the preparation of a variety of ether or thioether substituted phthalonitriles[20], [21]. Cyclotetramerization of the phthalonitrile derivatives 2 and 3 in a high-boiling solvent npentanol in the presence of a few drops 1,8diazabicyclo[5.4.0] undec-7-ene DBU as a strong base and anhydrous $\mathrm{Zn}\left(\mathrm{CH}_{3} \mathrm{COO}\right)_{2}$ at reflux temperature under a nitrogen atmosphere afforded the zinc phthalocyanines4 and $\mathbf{5}$. Purification of the novel synthesized phthalocyanines was achieved by column chromatography on silica gel by using $\mathrm{CH}_{2} \mathrm{Cl}_{2}$ and $\mathrm{C}_{2} \mathrm{H}_{5} \mathrm{OH}$ mixtures as the eluent. The route for the synthesis of compounds (2-5) is shown in Scheme 1. The characterization of the compounds was carried out by the combination of several methods, including elemental analysis, IR, ${ }^{1} \mathrm{H}$ NMR, ${ }^{13} \mathrm{C} \mathrm{NMR}$, mass characterization techniques and UV-vis spectra. The compounds structures were confirmed by the results of these analyses.

The $-\mathrm{C} \equiv \mathrm{N}$ band in the IR spectrum of compound $\mathbf{2}$ was observed, as expected, at 2226 and $2232 \mathrm{~cm}^{-1}$ for 3 . Also the appearance of new absorptions at $910-827$ and $914-839 \mathrm{~cm}^{-1}$ belonging to $(\mathrm{C}-\mathrm{S}-\mathrm{C})$ confirmed the proposed structures of the compounds 2 and $\mathbf{3}$ respectively.In the ${ }^{1} \mathrm{H}$ NMR spectrum of compound 3 , the $\mathrm{CH}_{2}$ protons and the other $\mathrm{CH}_{2}$ were observed at $\delta=2.6-2.57$ and $\delta=3.2-3.15 \mathrm{ppm}$ as multiplet, respectively. The aromatic protons appear at $\delta=7.9-7.4$. The singlet $\mathrm{CH}_{3}$ protons were at $\delta=3.8 \mathrm{ppm}$. The structure of compound 3 is confirmed by ${ }^{13} \mathrm{C}$ NMR spectrum. Stable molecular ion $[\mathrm{M}]^{+}$peaks $\mathrm{m} / \mathrm{z}$ at 232.26 and 246.29 in the mass spectra of compounds $\mathbf{2}$ and $\mathbf{3}$ were reflected that target compounds were successfully prepared. The most important proof of the cyclotetramerization of nitrile groups is the absence of the $-\mathrm{C} \equiv \mathrm{N}$ vibrations at $2226 \mathrm{~cm}^{-1}$ and 2232 $\mathrm{cm}^{-1}$ for compounds 2 and 3 respectively in IR spectra of the substituted phthalocyanine compounds (4 and 5). The rest of the spectra were not very different from that of the corresponding phthalonitrile compounds.

\subsection{Ground state electronic absorption and aggregation properties}

All substituted zinc (II) phthalocyanines were soluble in most of organic solvents such as tetrahy-drofuran (THF), dichloromethane(DCM) and dimethyl sulfoxide(DMSO). Phthalocyanines display typical electronic spectra with two absorption regions, one is called Q-band at around $600-700 \mathrm{~nm}$ and arise from $\pi-\pi \mathrm{n}$ transitions from highest occupied molecular orbital (HOMO) to the lowest unoccupied molecular orbital (LUMO) of the Pc ring, other one is called B-band at around $300-350 \mathrm{~nm}$ and result from deeper $\pi$ levels-LUMOtransitions [22]. The spectral data are listed in Table 1.

Table 1: UV-visible data for the phthalocyanine compounds

\begin{tabular}{|c|c|c|c|}
\multicolumn{4}{|c}{$\mathbf{5}-\mathbf{6}$} \\
\hline \multirow{2}{*}{ Compound } & \multirow{2}{*}{ Solvent } & \multicolumn{2}{|c|}{$\boldsymbol{\lambda}_{\max } / \mathbf{n m}\left(\mathbf{l o g} \mathbf{\varepsilon} / \mathbf{d m}^{\mathbf{3}} \mathbf{~ m o l}^{-\mathbf{1}} \mathbf{~ m m}^{-\mathbf{1}}\right)$} \\
\cline { 3 - 4 } & & B band & Q band \\
\hline $\mathbf{4}$ & THF & $340(4,42)$ & $616(4,18), 678(4,49)$ \\
\hline $\mathbf{5}$ & THF & $348(4,18)$ & $615(3,83), 681(4,34)$ \\
\hline
\end{tabular}

Aggregation is usually depicted as a coplanar association ofrings progressing from monomer to dimer and higher order complex. It is dependent on the concentration, nature of the solvent,nature of the substituents, complexed metal ions and temperature. Non-aggregated phthalocyanines have received considerableattention. Phthalocyanine compounds have a high aggregation tendency due to the interaction between their $18 \pi$ electron systems and the aggregation decreases the solubility of these compounds in solvents. These compounds, normally with thioester substituents,possess good solubility, which can facilitate the purification andcharacterization processes. The non-aggregated nature can alsoprevent undesirable effects arising from stacking of molecules [23].Generally the increasing concentration of Pcs leads to aggregation, which is observed by the position of Q bands, which shift tohigher energies by a parallel decrease in the molar absorption. Theaggregation behavior of the phthalocyanine complexes $\mathbf{4}$ and $\mathbf{5}$ were also investigated at different concentrations in THF(Figure 1 for compound 4and Figure $\mathbf{2}$ for compound $\mathbf{5}$ ).

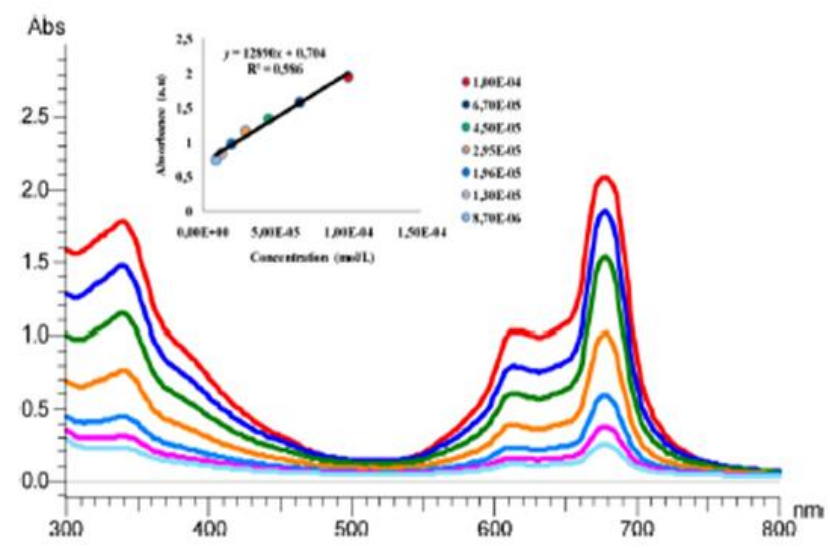

Figure 1: The aggregation behavior of phthalocyanine4 


\section{International Journal of Science and Research (IJSR) \\ ISSN (Online): 2319-7064}

Index Copernicus Value (2013): 6.14 | Impact Factor (2015): 6.391

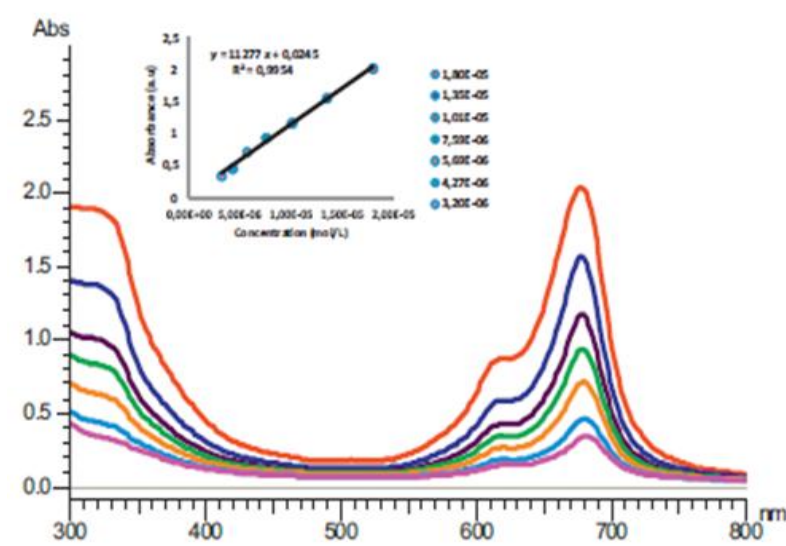

Figure 2: The aggregation behavior of phthalocyanine5

In THF, asthe concentration was increased, the intensity of absorption of the $\mathrm{Q}$ band corresponding to monomeric species also increased andthere were no new bands due totheaggregated species for bothof the complexes. Beer-Lambert law was obeyed in the concentrations ranging from $8.7 \times$ $10^{-6}$ to $1 \times 10^{-4}$ for compound 4 and from $3.2 \times 10^{-6}$ to $1 \times$ $10^{-5} \mathrm{M}$ for compound 5 , respectively. Dueto the nature of methyl 2-mercaptoacetate and methyl 3-mercaptopropanoate substituents, it can clearly be concluded that the phthalocyaninesderivatives (4 and 5) did not show aggregation in THF for the studied concentrations.

\subsection{Scavenging activity on DPPH radicals}

DPPH free radical scavenging activity is described as a simple, fast, widely used and suitable method independent of sample polarity for measuring of many samples for free radical scavenging ability [24], [25]. DPPH certainly accepts an electron or hydrogen radical to become a stable diamagnetic molecule which is relatively stable nitrogen centered free radical [26]. This activity can be used to quickly determine the antioxidant capacity [27]. Newly synthesized compounds 4 and 5 were experimented for free radical scavenging ability. Ascorbic acid and Trolox were used as standard compounds. The DPPH free radical scavenging activity increased with the increasing concentrations of studied compounds 4 and 5 (figure3).

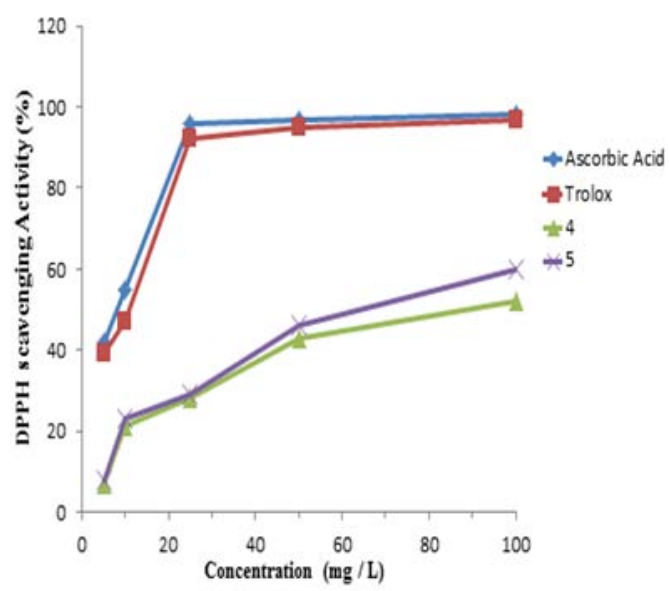

Figure 3: Radical-scavenging activity on DPPH radicals (\%) of thecompounds
The maximum free radical scavenging activity was found as $44.8 \%$ for compound 5 at the concentration of $100 \mathrm{mg} / \mathrm{L}$ and the mini-mum DPPH activity was found to be $17.6 \%$ with 6 at $100 \mathrm{mg} / \mathrm{mL}$. The results revealed that all of the DMF solution of compounds showed low DPPH radical scavenging activity compared to Ascorbic acid and Trolox.

\subsection{Antibacterial activity}

In this study, antibacterial activity of compounds was also investigated. The phthalocyanine compounds were studied for in vitro antibacterial activity by the disk diffusion method. The results of antibacterial activities of test compounds are demonstrated in Table 2.

Table 2: Antimicrobial activity of compounds and standard antibiotics

\begin{tabular}{|c|c|c|c|c|}
\hline \multirow{2}{*}{ Bacteria } & \multicolumn{4}{|c|}{ Compounds and standard antibiotic disks } \\
\cline { 2 - 5 } & $\mathbf{4}$ & $\mathbf{5}$ & $\mathbf{A K}$ & TE \\
\hline P. aeruginosa & 11 & 12 & 20 & 24 \\
\hline E. coli & 9 & 10 & 24 & 24 \\
\hline S. aureus & 8 & 9 & 22 & 24 \\
\hline M. luteus & 12 & 14 & 16 & 24 \\
\hline
\end{tabular}

a Inhibition diameter in millimeters. AK $=$ Amikacin $(30 \mu \mathrm{g})$, $\mathrm{TE}=$ Tetracycline $(30 \mu \mathrm{g})$

It was obtained that, compounds $\mathbf{4}$ and $\mathbf{5}$ showed antibacterial activity against all bacteria. These observations are similar to earlier report by Tarafder et al. [28]. Among the tested compounds, compound $\mathbf{5}$ showed higher antibacterial ability followed by compound $\mathbf{4}$ against all studied bacteria. However, the tested standard antibiotics exhibited more antibacterial activity than the phthalocyanine complexes.

\section{Conclusion}

In conclusion, the present work describes the synthesis andcharacterization of phthalocyanines bearing methyl 2mercaptoacetate and methyl 3-mercaptopropanoate substituents on the peripheral positions have been reported and these new complexes were characterized by elemental analysis, FTIR, ${ }^{1} \mathrm{H}$ NMR spectroscopy, electronic spectroscopy and mass spectrometry. The synthesized phthalocyanine complexes show excellent solubility in organic solvents such as, $\mathrm{CHCl}_{3}, \mathrm{CH}_{2} \mathrm{Cl}_{2}$, THF, DMF and DMSO. The aggregation behaviors of compounds $\mathbf{4}$ and $\mathbf{5}$ were investigated. These phthalocyanines showed monomeric behaviors in THF for studied concentration ranges. In addition, the antioxidant and antibacterial activities of compounds were investigated. With regard to the scavenging effect on free radical scavenging activity, compound $\mathbf{5}$ was the highest at concentration of 100 $\mathrm{mg} / \mathrm{L}$ whereas the other compounds were low. All compounds were screened for antibacterial activity and the highest antibacterial activity of compounds $\mathbf{4}$ and $\mathbf{5}$ exhibited moderate to good activity against $\mathrm{M}$. luteus and $\mathrm{P}$. aeruginosa, respectively

\section{References}

[1] N.B. McKeown, Phthalocyanines Materials - Synthesis, in: Structure and Functions, Cambridge University Press, Cambridge, 1998. 


\section{International Journal of Science and Research (IJSR) \\ ISSN (Online): 2319-7064}

Index Copernicus Value (2013): 6.14 | Impact Factor (2015): 6.391

[2] A. Erdogmus, T. Nyokong, Dyes and Pigments (86), pp 174-181, 2010.

[3] M.S. Agırtas, I. Gümüs, V. Okumus, A. Dundar, Z. Anorg. Allg.Chem. (638), pp1868, 2012.

[4] Y.L. Lee, C.H. Chang, Sens. Actuators, (B 119), pp 174, 2006.

[5] C.B. Yao, Y.D. Zhang, D.T. Chen, H.T. Yin, C.Q. Yu, J. Li, P. Yuan, Optics LaserTechnol. (47), pp 228, 2013.

[6] F. Yuksel, M. Durmus , V. Ahsen, DyesPigm (90), pp 191-200, 2011.

[7] N. Masilela, T. Nyokong, DyesPigm. (84), pp 242, 2010.

[8] S. Wei, S. Huang, L. Li, Q. Meng, Dyes Pigments (56), 2003.

[9] M.S. Agurtas, Inorg. Chim. Acta (360), pp 2499, 2007.

[10] O. Bekaroglu, Appl. Organomet. Chem. (10), pp 605, 1996.

[11]D. Li, Y. Tong, J. Huang, L. Ding, Y. Zhong, D. Zeng, P. Yan, J. Mol. Catal. A: Chem.(345), pp108, 2011.

[12] M.S. Agırtas, A. Altındal, B. Salih, S. Saydam, O. Bekaroglu, Dalton Trans. (40), pp 3315, 2011.

[13] M. Wojdyła, B. Derkowska, Z. Łukasiak, W. Bała, Mater. Lett.(60), pp 3441, 2006.

[14]H. Kantekin, Z. Biyıklıg lu, Dyes Pigm. (77), pp 432, 2008.

[15] F. Cong, B. Ning, Y. Ji, X. Wang, F. Ke, Y. Liu, X. Cui, B. Chen, Dyes Pigments (77), pp686, 2008.

[16]E. Güzel, A. Atsay, S. Nalbantoglu, N. Saki, A.L. Dogan, A. Gül, M.B. Koc, ak, Dyes Pigm. (97), pp 238 243, 2013.

[17] J.G. Young, W. Onyebuagu, J. Org. Chem. (55). pp 2155-2159, 1990.

[18]D. Kalemba, A. Kunicka, Curr. Med. Chem. (10), pp 813, 2003.

[19] M. Patel Rajesh, J. Patel Natvar, J. Adv. Pharm. Educ. Res (1), pp 52, 2011.

[20] A.K. Burat, Z.P. Oz, Z.A. Bayır, Monatsh. Chem. (143), pp 437-442, 2012.

[21] M. Selçukoglu, E. Hamuryudan, Dyes Pigm. (74), pp 17-20, 2007.

[22]A. Koca, A. Kalkan, Z.A. Bayır, ElectrochimicaActa (56), pp 5513-5525, 2011.

[23] K.P.Ng. Dennis, C. R. Chimie (6), pp 903, 2003.

[24] K. Marxen, K.H. Vanselow, S. Lippemeier, R. Hintze, A. Ruser, U.-P. Hansen, Sensors (7), pp 2080, 2007.

[25] J. Pérez-Jiménez, F. Saura-Calixto, Int. J. Food Sci. Technol. (43), pp 185, 2008.

[26] M. Patel Rajesh, J. Patel Natvar, J. Adv. Pharm. Educ. Res. (1), pp 52, 2011.

[27]E.J. Park, D.Y. Jhon, Food Sci.Technol.(43), pp 655, 2010.

[28] M.T.H. Tarafder, A. Kasbollah, K.A. Crouse, A.M. Ali, B.M. Yamin, H.K. Fun, Polyhedron (20), pp 2363, 2001.

Volume 5 Issue 8, August 2016 www.ijsr.net

Licensed Under Creative Commons Attribution CC BY 